\title{
EFFECT OF USING SLURRY INFILTRATED FIBER CONCRETE ON THE BEHAVIOR OF REINFORCED CONCRETE CORBELS
}

\author{
${ }^{*}$ Hajer K. Alqaraghouly ${ }^{1}$
}

Nibras N. Abdul-Hameed ${ }^{1}$

1) Civil Engineering Department, College of Engineering, Mustansiriyah University, Baghdad, Iraq

\begin{abstract}
This paper experimentally presents the behavior and strength of slurry infiltrated fiber concrete (SIFCON) corbels. The program included 3 specimens in which steel fiber volume fractions were varied $(6,8$, and 10$) \%$. All specimens had a constant shear span to depth ratio $(a / d=0.7)$ and were of the same width, length, and thickness. The corbel specimens were examined under the effect of concentrated vertical load only. It was found that the compressive strength, splitting tensile strength, modulus of rupture, modulus of elasticity, and failure mode were improved with the increase in steel fiber content for all SIFCON corbels.
\end{abstract}

Keywords: SIFCON, corbels, steel fibers, compressive strength, flexural, shear span, reinforced concrete, cracking load.

\section{Introduction}

Corbels or (brackets) are the parts that protrude from the face of columns or walls. They are widely used in precast concrete constructions to support precast beams, pre-stressed beams, girders, and transmit loads to the vertical parts of the structure.

Corbels are constructed monolithically with columns or walls. They behave as simple trusses or deep beams rather than as flexural members. Therefore, they are widely regarded as transmitters of shear forces. The term (corbels) is restricted to cantilevers with a shear span to depth ratio $(\mathrm{a} / \mathrm{d} \leq 1.0)[1]$ and the small value of $(\mathrm{a} / \mathrm{d})$ is the reason for the high strength of corbels.

Previous studies have demonstrated the effect of adding steel fibers on the behavior of concrete corbels. In most cases, the steel fibers were added as a replacement for the secondary reinforcement [2]. The performance in terms of stiffness, ductility, crack width, and load-carrying capacities recorded significant improvements with the increase in steel fiber content [3]. Also, it was found that the fibrous concrete corbels may fail more gradually and the failure mode is either inclined shear or flexure [4,5].

From this point of view, Slurry infiltrated fiber concrete (SIFCON) technology has been adopted in the present paper. SIFCON is a special type of fiber-reinforced concrete (FRC) in which fibers are filled into formwork molds to capacity. The resulting fiber bed is infiltrated by a cement slurry.

SIFCON has higher fiber content in comparison with FRC. It ranges from (4 to 20) $\%$ whereas (FRC) contains (1 to 3 ) $\%$ of fibers [6].

Coarse aggregates prevent SIFCON slurry from infiltration through the dense fibers [7]. 
Accordingly, SIFCON was produced without adding any type of coarse aggregates, even the coarser particles of sand were eliminated throughout this work. SIFCON shows outstanding mechanical properties in terms of ductility and energy absorption. Therefore, it has been used successfully in seismic resistance reinforced concrete members, pavement overlays, blast resistance structures, safe vaults, and repair bridges [8]. Hence, the current study maintains useful information to develop more general design criteria for SIFCON corbels under the effect of vertical loading only.

\section{Research Significance}

There is a lack of data and information on the SIFCON corbels due to the recent use of SIFCON in the construction field. The sizes of corbels can be reduced and failure modes can be enhanced if SIFCON is used in the manufacturing of corbels. Therefore, this investigation was carried out to fill the existing gap.

\section{Experimental Investigation}

Three double-sided SIFCON corbels were constructed. All specimens had a constant corbel depth of $250 \mathrm{~mm}$ and a column of (150 mm depth X $200 \mathrm{~mm}$ width X $650 \mathrm{~mm}$ length). Three different fiber volume fractions () of (6,8, and 10) $\%$ by volume were adopted. All SIFCON corbel specimens were of constant shear span to depth ratio $(\mathrm{a} / \mathrm{d})$ and they were subjected to vertical load only. Fig. 1 shows the details of the corbels and column dimensions.

Several trail mixes have been carried out to determine the dosage of superplasticizer and the amount of silica fume. The mixed proportions are listed in Table 1.

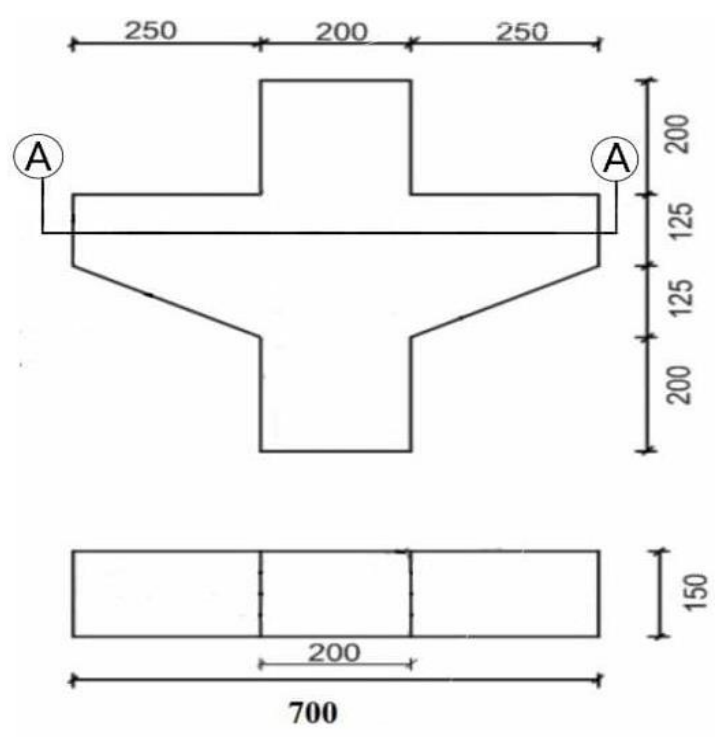

Section A-A

Figure 1. Details of the corbel specimen (all dimensions are in $\mathrm{mm}$ )

Table 1. The optimal proportions of the SIFCON mixture

\begin{tabular}{lc}
\hline Cement $\left(\mathrm{kg} / \mathrm{m}^{3}\right)$ & 898.2 \\
Sand $\left(\mathrm{kg} / \mathrm{m}^{3}\right)$ & 998 \\
Silica fume $\left(\mathrm{kg} / \mathrm{m}^{3}\right)$ 10\% rep. & 99.8 \\
Steel fibers $(\%)$ & 6,8, and \\
& 10 \\
w/b* ratio & 0.3 \\
SP (by wt. of cement) \% & 3.7 \\
\hline
\end{tabular}

${ }^{*} \mathrm{w} / \mathrm{b}=$ water/binder $=$ water/(cement+silica fume)

\section{Material Properties}

\subsection{Cement}

Ordinary Portland cement produced at Kubaisa Cement Plant was used during the current investigation and it was confirmed to meet the requirements of Iraqi specifications No. 45/1984 [9].

\subsection{Fine Aggregates}

Natural sand passing through a $(1.18 \mathrm{~mm})$ sieve to eliminate the coarser particles was used to produce the flowable SIFCON slurry in this investigation. The fine aggregate grading is 
shown in Fig.2, which meets the requirements of the Iraqi specifications No. 45/1984 [9]

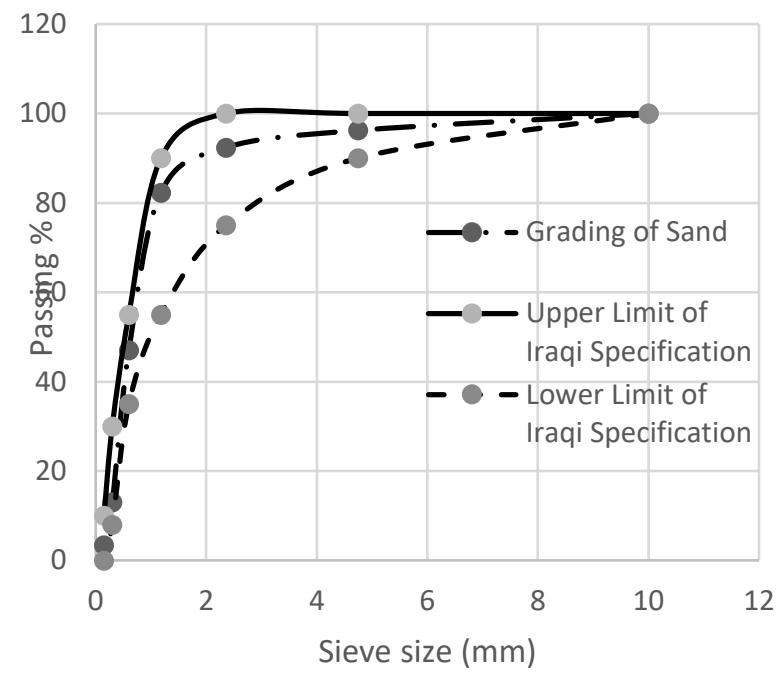

Figure 2. Sieve analysis of sand

\subsection{Water}

Tap water was used for mixing and curing all of the SIFCON corbels.

\subsection{Steel Fibers}

Hooked-end steel fibers of high tensile strength from Bunbrex company in Korea and complying with ASTM C 1550-05 [10] requirements were used with three different volume fractions $(6,8$, and 10) $\%$. Table 2 illustrates the properties of steel fibers.

\subsection{Superplasticizer}

In this work, a chloride-free superplasticizer known as (Visco-Crete-5930L) was used. It is produced by Sika Company. It conforms to the requirements of ASTM-C [11] and BS EN 934 part 2: 2001 [12]. The typical properties of ViscoCrete-5930L are presented in Table 3.
Table 2. The properties of hooked end steel fibers*

\begin{tabular}{ccc}
\hline Property & $\begin{array}{c}\text { Result of steel } \\
\text { fibers }\end{array}$ & $\begin{array}{c}\text { (ASTM C } \\
\text { 1550-05) }\end{array}$ \\
\hline Description & $\begin{array}{c}\text { Deformed shape } \\
\text { hooked end } \\
\text { Bppearance } \\
\text { Bright and clean } \\
\text { wire }\end{array}$ \\
Length (L), mm & 35 \\
Diameter (d), mm & 0.55 \\
Aspect ratio & 64 \\
Density (kg/m ${ }^{3}$ ) & 7800 \\
Tensile strength \\
(Mpa) \\
*According to manufacturer (Bunbrex company)
\end{tabular}

Table 3. Typical properties of Visco-Crete -5930L*

\begin{tabular}{ccc}
\hline No. & Main action & Concrete superplasticizer \\
\hline 1 & Based on & Modified polymer \\
2 & pH. Value & $4-6$ \\
3 & Density & $0.01 \pm 1.083$ \\
4 & Solid materials & $0.01 \pm 37$ \\
& ratio & \\
\hline
\end{tabular}

*From manufacturer catalog

\subsection{Silica Fume}

Densified micro silica from Sika Company was used as a partial replacement of $10 \%$ by weight of cement. It meets the requirements of ASTM C1240 [13] specifications. 


\section{Mechanical Properties of Hardened SIFCON}

\subsection{Compressive Strength $\left(f_{c}^{\prime}\right)$}

The most important property of hardened concrete is its compressive strength. The compressive strength test was performed on three cylinders (100 mm diameter X $200 \mathrm{~mm}$ height) with three different volume fractions of steel fibers (6,8 and 10) \% at age 28 days according to ASTM C39 [14]. Fig.3 (a) demonstrates the compressive failure pattern. It was found that the compressive strength values increased with the increase of steel fiber. When steel fiber content increased from (6-10) \%, the compressive strength increased by about $8.73 \%$ as shown in Table 4 and Fig.4. SF6, SF8, and SF10 refer to SIFCON mixtures with $(V f=6,8$, and 10$) \%$, respectively.

Table 4. Compressive strength results of SIFCON

\begin{tabular}{cc}
\hline Mix & $\begin{array}{c}f_{c}^{\prime *} \\
\text { Mpa }\end{array}$ \\
\hline SF6 & 126 \\
SF8 & 133.69 \\
SF10 & 137 \\
\hline
\end{tabular}

* Compressive strength is the average of two values

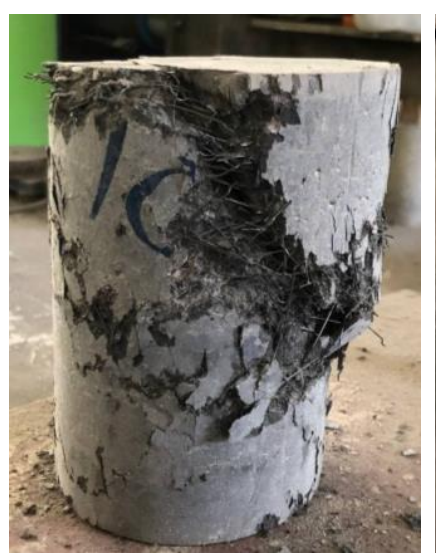

(a)

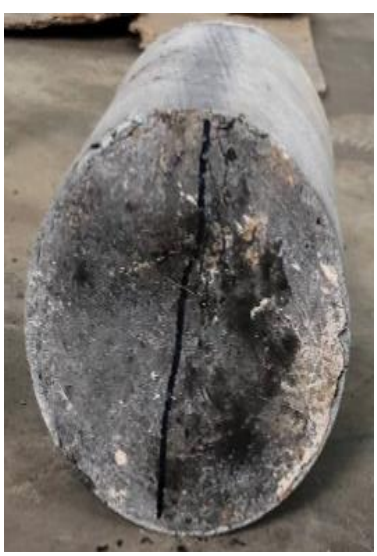

(b)

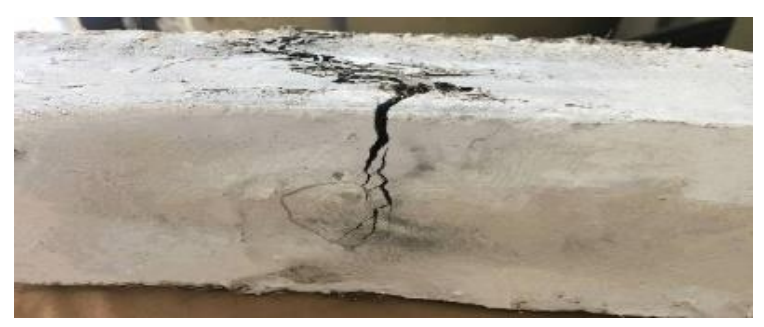

(c)

Figure 3. Failure patterns of cylinders and prisms

(a) compressive fracture pattern

(b) splitting tensile fracture pattern

(c) prism failure pattern

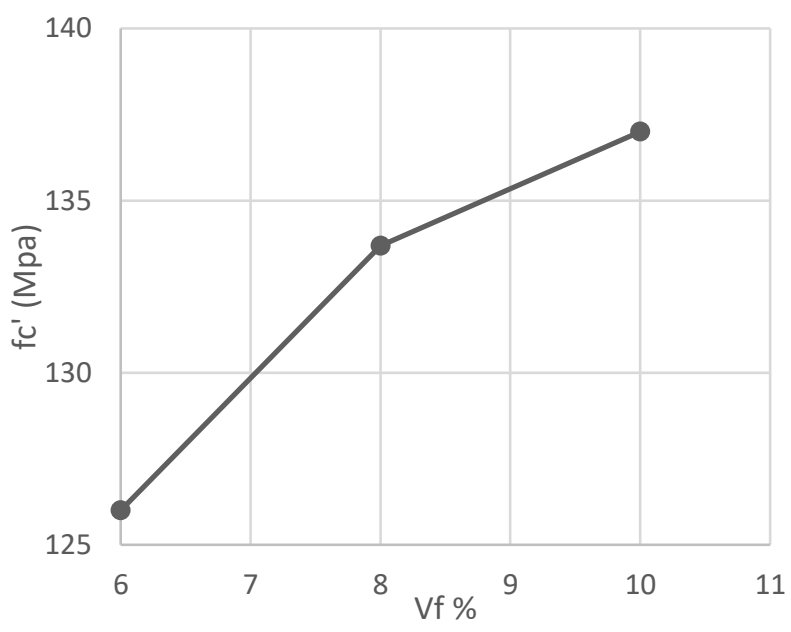

Figure 4. Relationship between the compressive strength and steel fiber content for SIFCON corbels

\subsection{Splitting Tensile Strength $\left(\boldsymbol{f}_{t}\right)$}

Tensile stress is the main reason for the formation of cracks in concrete. The splitting tensile strength should be taken into consideration.

In the current study, a splitting tensile strength test was performed for (100 mm diameter X 200 $\mathrm{mm}$ height) cylinders in accordance with ASTM C496-04 [15]. Fig.3 (b) illustrates the splitting tensile failure pattern. From the test results, it is obvious that the increase in steel fiber volume fraction from (6-10) \% leads to an enhancement of the splitting tensile strength by about $38.77 \%$ as presented in Table 5 and Fig. 5. 
Table 5. Splitting tensile strength results of SIFCON

\begin{tabular}{cc}
\hline Mix & $f_{t}(\mathrm{Mpa})$ \\
\hline SF6 & 12.25 \\
SF8 & 15.87 \\
SF10 & 17 \\
\hline
\end{tabular}

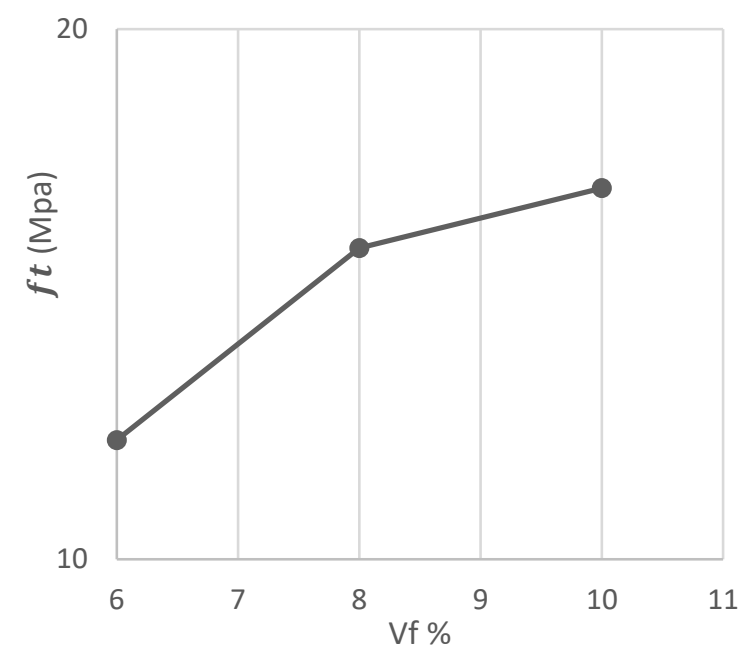

Figure 5. Relationship between splitting tensile strength and steel fiber content for SIFCON corbels

\subsection{Modulus of Rupture (fr)}

The modulus of rupture refers to the maximum tensile stress for concrete being tested in flexural. Three prisms of (100 mm width $\mathrm{x} 100 \mathrm{~mm}$ length x $500 \mathrm{~mm}$ depth) were adopted for testing according to ASTM C-78 [16]. Fig.3 (c) shows the failure pattern and Table 6 presents the results of the tested prisms. The increase in the fractional volume of steel fibers from (6-10) \% leads to an enhancement of the flexural strength (modulus of rupture) by about $26.55 \%$ as shown in Fig. 6

Table 6. Flexural strength results of SIFCON

\begin{tabular}{cc}
\hline Mix & $\mathrm{f}_{\mathrm{r}}$ (Mpa) \\
\hline SF6 & 22.125 \\
SF8 & 25.635 \\
& \\
SF10 & 28 \\
\hline
\end{tabular}

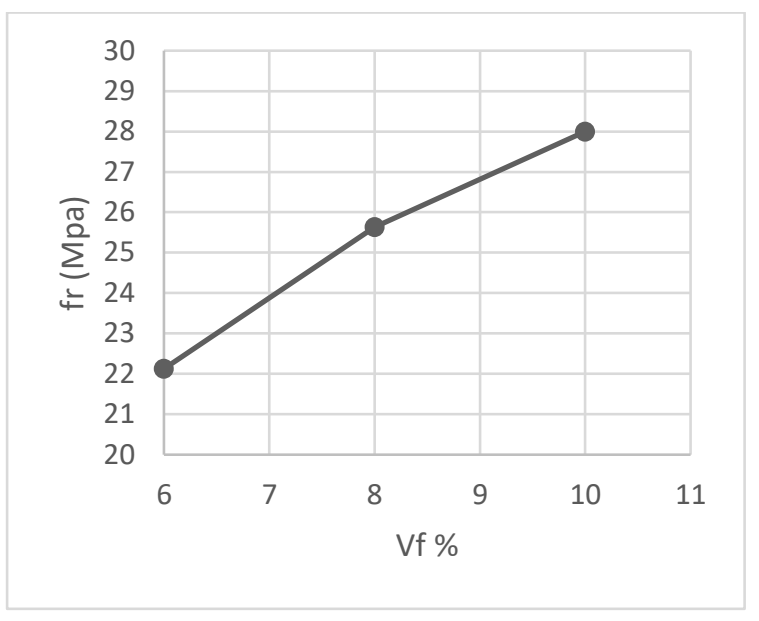

Figure 6. Relationship between modulus of rupture and steel fiber content for SIFCON corbels

\section{Test Results of SIFCON Corbels}

All SIFCON corbel specimens were set up in an upside-down position and tested at the age of 28 days under the effect of vertical load only by using the Universal Hydraulic Testing Machine with a $3000 \mathrm{kN}$ capacity in the Structural Laboratory at Mustansiriyah University, see Fig. 7. The values of ultimate load $(V u)$ and the first cracking load $(V c r)$, as well as the main variables handled in this study, are listed in Table 7. CS6, CS8, and CS10 refer to SIFCON corbels with $(V f=6,8$, and 10$) \%$, respectively.

Table 7. Experimental first cracking and ultimate loads of SIFCON corbels

\begin{tabular}{|c|c|c|c|c|c|}
\hline $\begin{array}{c}\text { Corbel } \\
\text { name }\end{array}$ & $\begin{array}{l}\mathrm{a} / \mathrm{d} \\
\text { ratio }\end{array}$ & $\begin{array}{l}V_{f} \\
(\%)\end{array}$ & $\begin{array}{l}V c r \\
(\mathrm{kN})\end{array}$ & $V u(\mathrm{kN})$ & $\begin{array}{l}\text { Failure } \\
\text { mode }\end{array}$ \\
\hline CS6 & 0.7 & 6 & 112.5 & 430 & $\mathrm{~F}^{*}$ \\
\hline CS8 & 0.7 & 8 & 118 & 600 & F \\
\hline CS10 & 0.7 & 10 & 145 & 730 & $\mathrm{~F}$ \\
\hline
\end{tabular}




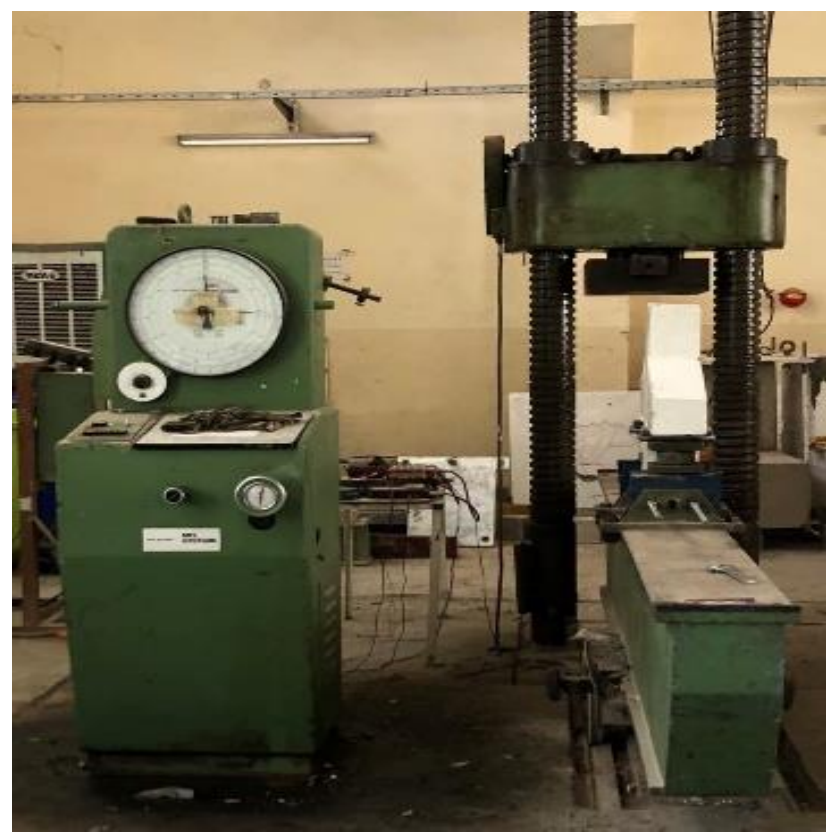

Figure 7. Testing machine

\section{The Behavior of SIFCON Corbels Specimens}

At the early loading stages, the displacement is very small and the cracks have not developed yet due to the small amount of stress applied to the corbels.

The first cracks that appeared were of the flexural type. They began at or near the crossline between the corbel and the column and propagated slowly inside the corbel or along the face of the column.

At later stages, and with the increase in the applied load, the flexural cracks were still the only crack type observed and became clearer in appearance due to the high resistance of steel fibers to the tensile stresses across the cracks, which led to enhanced shear strength for SIFCON corbels. Therefore, no shear cracks were figured out throughout the testing stages [17], as shown in Fig. 8.

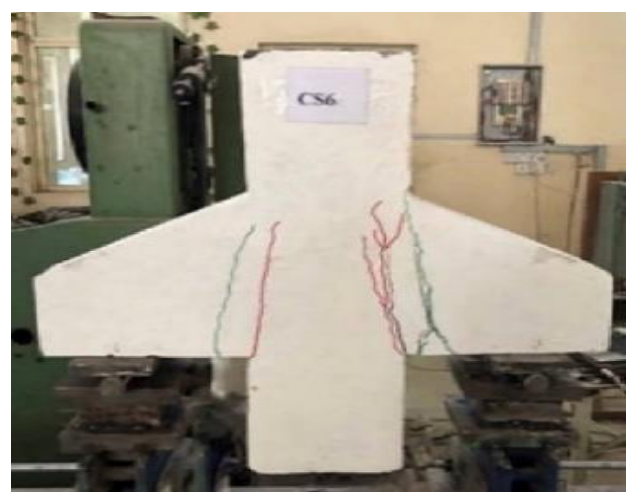

(a)

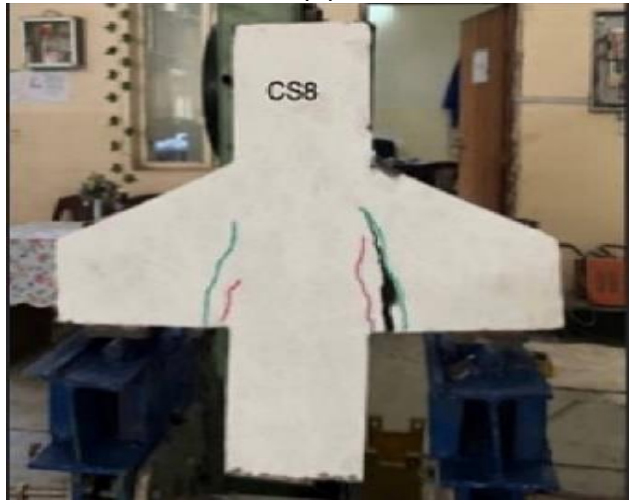

(b)

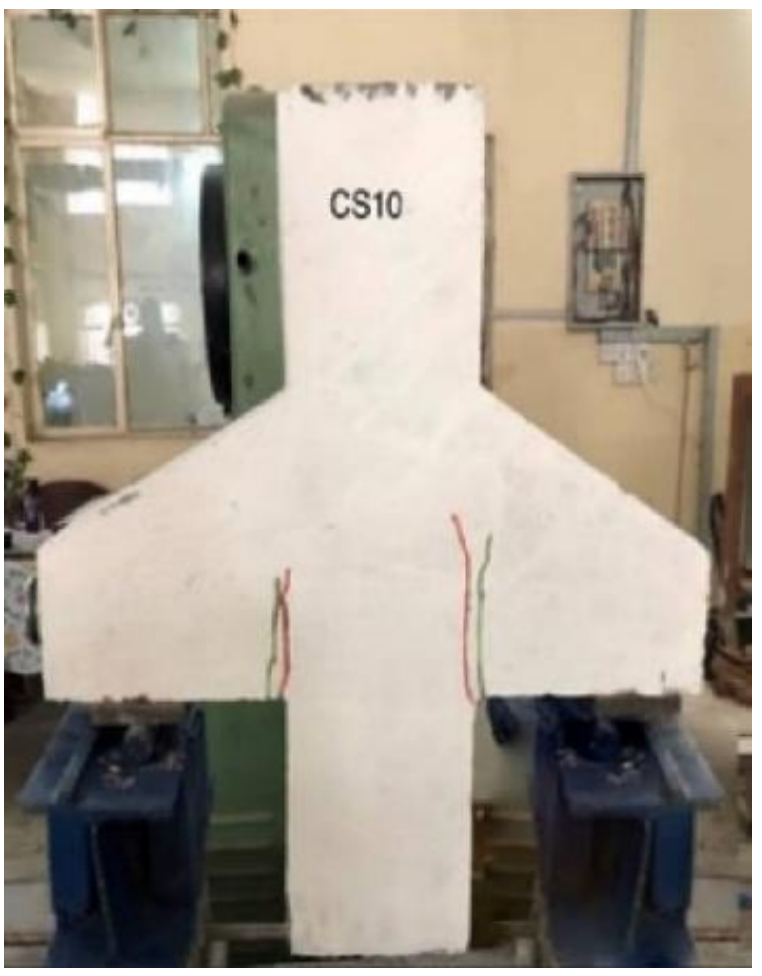

c)

Figure 8. Cracks patterns of SIFCON corbels after testing.

(a) Cracks patterns of corbel CS6

(b) Cracks patterns of corbel CS8

(c) Cracks patterns of corbels CS10 


\subsection{Load-Deflection Response of SIFCON Corbels Specimens}

The deflection that occurred due to applied loadings was measured by using a dial gauge of $(0.01 \mathrm{~mm})$ accuracy, which was attached to the column center of the corbel specimen as shown in Fig.9. It was found that the deflection values decreased with the increase in steel fiber content. Deflection values at a certain load level $(250 \mathrm{kN})$ of corbels CS6 $(V f=6 \%), \operatorname{CS} 8(V f=8 \%)$, and CS10 (Vf $=10 \%)$ are $1.75 \mathrm{~mm}, 1.57 \mathrm{~mm}$, and $1.36 \mathrm{~mm}$ respectively. Load-deflection curves for each SIFCON corbel specimen are shown in Fig. 10.

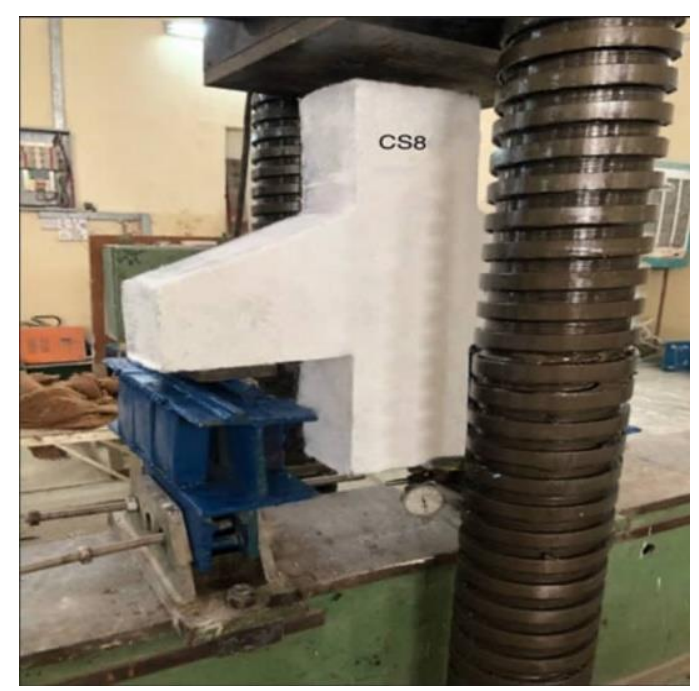

Figure 9. Set up of corbel specimen

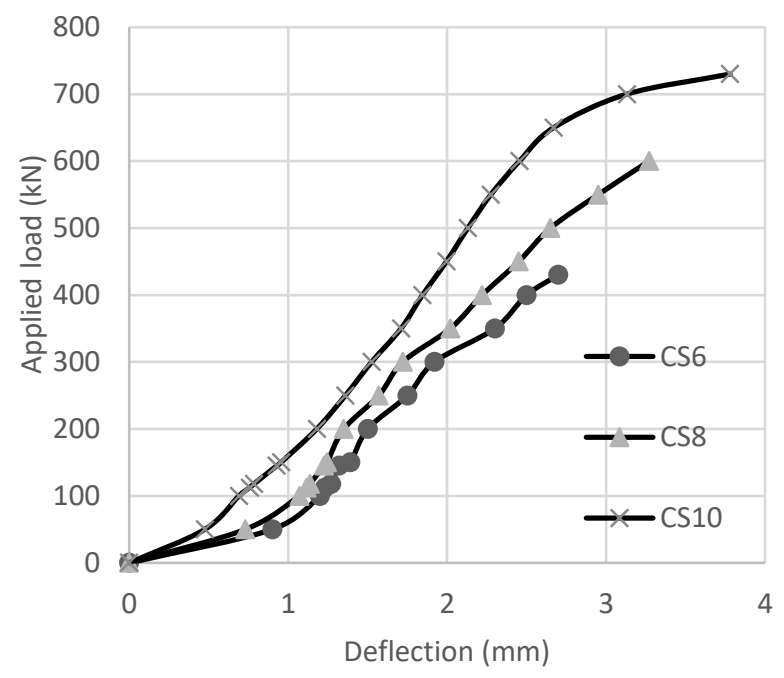

Figure 10. Load-deflection curves of SIFCON corbel
Due to the presence and the large values of steel fibers used in this work, significant improvement in cracking resistance of concrete was recorded as well as the formation of the first cracks and the propagation of cracks during the later loading stages was delayed.

\subsection{Effect of Steel Fibers on Ultimate Load and Cracking Capacity}

Steel fibers can enhance the resistance of concrete mixtures to the propagation of cracks. This type of fiber holds parts of the concrete section together and bridges the side of the crack effectively until the last loading level is reached. This delays the cracks from reaching the compression zone of the concrete section. In this study, the SIFCON corbels were strengthened with three different fractional volume percentages $(6,8$, and 10$) \%$ by volume. It was clear from the test results that with the increase in steel fiber percentage, the cracking resistance and the ultimate loading capacity increased significantly, as well as delaying the appearance of the first crack. The ultimate load increased by about $69.77 \%$ when steel fiber content increased from (6-10) \%, while the increase in cracking load was $28.89 \%$ when the fractional volume of steel fibers increased from (6-10) \%. See Figs. 11 and 12 and Table 7.

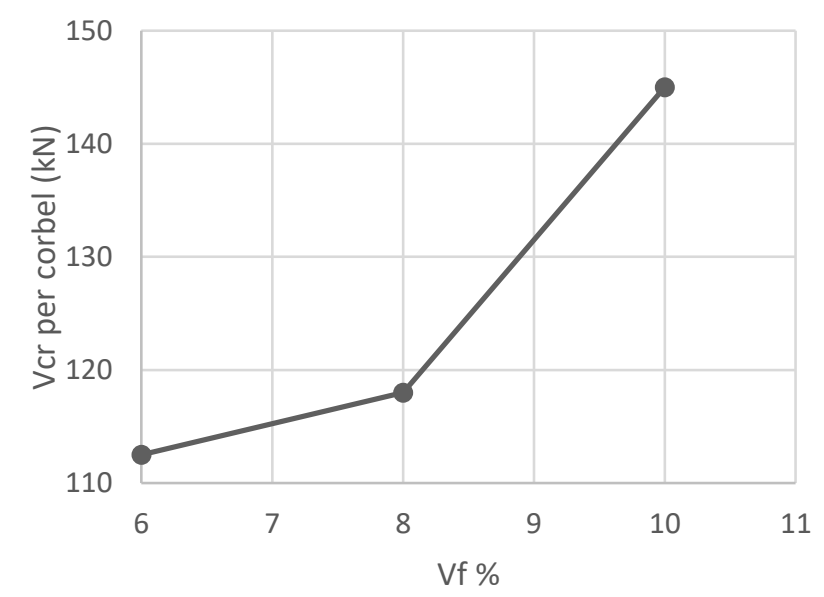

Figure 11. Effect of fiber volume fraction on cracking load of SIFCON corbels 


\subsection{Failure Modes}

In the current study, two types of failure modes have been characterized.

\subsubsection{Flexural Tension Failure}

This failure mode occurs at the attachment of the column-corbel face after extensive yielding of the tension reinforcement in which the cracks propagate vertically and have a very wide opening appearance [18]. This type of failure is very obvious in both corbels CS6 and CS8, which are illustrated in Fig. 8 (a).

\subsubsection{Flexural Compression Failure}

Flexural compression failure mode occurs at the attachment of the column-corbel face before extensive yielding of the tension reinforcement. The cracks are with small openings and the tension reinforcement steel is found to be either lower than the yield point or just at the yield point [18]. Also, the failure is more ductile and gradually happens. Corbel CS10 has characterized this failure type as shown in Fig. 8 (b).

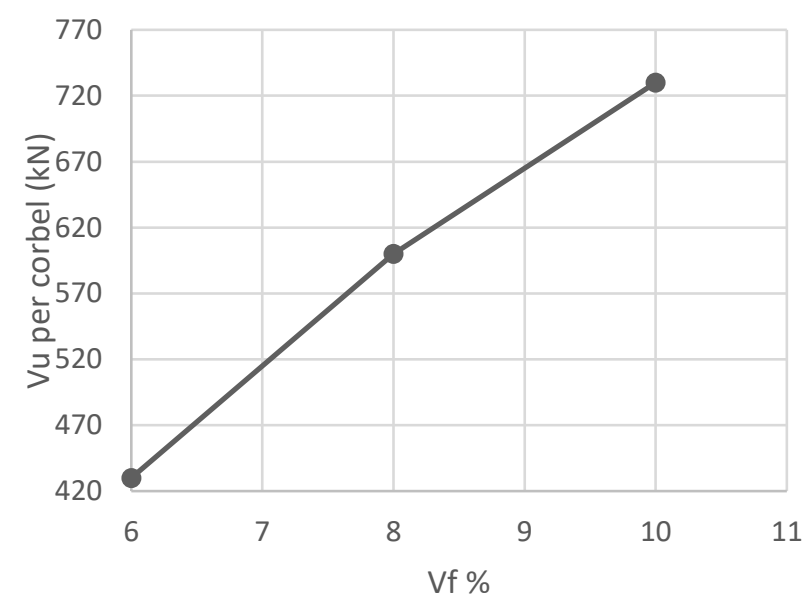

Figure 12. Effect of fiber volume fraction on the ultimate load of SIFCON corbels

\subsubsection{Effect of SIFCON on Corbel Failure Modes}

Since the flexural strength of SIFCON is greater than the flexural strength of fiber reinforced concrete (FRC), it is increased with the increase of fiber volume fraction for a certain limit that seems to be in a range of about (8-10) \% [7]. The crack patterns were grown at the surface and they were finer and not deep for the SIFCON corbel CS10 with the highest fiber volume fraction, i.e. (10) $\%$ by volume. On the other hand, SIFCON corbels specimens CS6 and CS8 with (6 and 8) $\%$ fibers had crack patterns that were deeper and wider than CS10 as presented in Fig.8.

\section{Conclusions}

1. The mechanical properties of SIFCON corbels have been improved successfully with the increase in steel fiber content.

2. With the increase in steel fiber content of SIFCON corbels from (6-10) $\%$, the deflection values for a certain load level (250 $\mathrm{kN}$ ) decreased by about $22.29 \%$.

3. The increase in steel fiber volume fraction led to fair enhancement in both cracking capacity and ultimate load for SIFCON corbels.

4. The failure mode of SIFCON corbels was a flexural failure, i.e., either flexural compression failure or flexural tension failure.

5. The large fractional volume of steel fibers of SIFCON corbels was representative of crack bridging and helped a lot in holding the crack sides together strongly. Therefore, the propagation of cracks was slight and in a gradual manner.

\section{Acknowledgments}

I would like to thank the supervisor of the research Asst. prof. Dr. Nibras Nizar and my niece Noor Al Zaman for their support. I am also grateful for all the help I received from my family members to support the whole research program.

\section{Conflict of Interest}

The authors confirm that the publication of the current paper does not cause a conflict of interest. 


\section{References}

1. ACI committee 318M-19 (2019). "Metric building code requirements for structural concrete and commentary". American Concrete Institute.

2. Khaleel, S. I., Ali, B. A., and Othman, Z. S. (2017). "Shear strength and behavior of reinforced concrete corbels containing either carbon fibers or stirrups". (Zanco Journal of Pure and Applied Sciences, Vol. 29, No. 5, pp. 10-21.

3. Yang, J. M., Lee, J. H., Yoon, Y. S., Cook, W. D., and Mitchell, D. (2012). "Influence of steel fibers and headed bars on the serviceability of high-strength concrete corbels". Journal of Structural Engineering, Vol. 138, No. 1, pp. 123-129.

4. FattuhiI, N. I. (1989). "Reinforced steel fiber concrete corbels with various shear span- todepth ratios". American Concrete Institute, Vol. 86, No. 6, pp. 590-596.

5. Fattuhi, N. I. (1990). "Strength of SFRC corbels subjected to vertical load". Journal of Structural Engineering, Vol. 116, No. 3, pp. 701-718.

6. Mohan, R. and Pannem, R. (2017). "Punching strength and impact resistance study of SIFCON with different fibers". International Journal of Civil Engineering and Technology, Vol. 8, Issue 4, pp. 11231131.

Gilani, A. M. (2007). "Various durability aspects of slurry infiltrated fiber concrete". Ph.D. Thesis. The Graduate School of Natural and Applied Science; Middle East Technical University, Ankara, Turkey.

7. Ali, M. A. A. (2018). "Properties of slurry infiltrated fiber concrete (SIFCON)". Ph.D.Thesis, Department of Building and Construction Engineering; University of Technology, Baghdad, Iraq.

8. IQS No. 5. (1984). "Portland cement," Central Agency for Standardization and Quality Control, Planning Council, Baghdad, Iraq, translated from Arabic edition.

9. ASTM C1550-05. (2005). "Standard test method for flexural toughness of fiber reinforced concrete (using centrally loaded round panel)”. ASTM International, West Conshohocken, PA, USA.

10. ASTM C494 / C494M-19. (2019). "Standard specification for chemical admixtures for concrete”. ASTM International, West Conshohocken, PA, USA.

11. BS EN 934-2(2001). "Admixtures for concrete, mortar and grout. Concrete admixtures - Definitions, requirements, conformity, marking and labelling (AMD 15448)", British Standards Institution.

12. ASTM C1240-20. (2020). "Standard specification for silica fume used in cementitious mixtures". ASTM International, West Conshohocken, PA, USA.

13. ASTM C39 / C39M-21. (2021). "Standard test method for compressive strength of cylindrical concrete specimens". ASTM International, West Conshohocken, PA, USA.

14. ASTM C496 / C496M-04. (2004). "Standard test method for splitting tensile strength of cylindrical concrete specimens". ASTM International, West Conshohocken, PA, USA.

15. ASTM C78 / C78M-21. (2021). "Standard test method for flexural strength of concrete (Using Simple Beam with Third-Point Loading)". ASTM International, West Conshohocken, PA, USA.

16. Lantsoght, E. O. (2019). "How do steel fibers improve the shear capacity of reinforced concrete beams without stirrups?". Composites Part B: Engineering, Vol. 175, 107079.

17. Canha, R. M. F., Kuchma, D. A., El Debs, M. K., and de Souza, R. A. (2014). "Numerical analysis of reinforced high strength concrete corbels". Engineering Structures, Vol. 74, pp. 130-144. 